\title{
Три Николая и Федор Мильков
}

\author{
В.И. Федотов \\ Воронежский государственный университет, Российская Федерация \\ (394018, г. Воронеж, Университетская пл., 1)
}

\begin{abstract}
Аннотация: Цель статьи - познакомить географическую общественность с новыми биографическими материалами о профессоре Ф.Н. Милькове.

Maтериаль и методы. Использованы при анализе взаимоотношений ученых опубликованные научные статьи и архивные материалы, хранившиеся у профессора Ф.Н. Милькова.

Результаты и обсуждение. В статье акцентируется внимание на профессиональные и личностные отношения между профессором Ф.Н. Мильковым и тремя известными в науке профессорами географического факультета Московского университета Н. А. Гвоздецким, Н. И. Михайловым и Н. А. Солнцевым. В центре внимания находятся проблемы научного сотрудничества, дружеских отношений и конфликты.

Заключение. Девяностые годы ХХ столетия - время ухода из жизни ярких, самобытных, бескомпромиссных ученых, оставивших значительный багаж знаний о природе нашей Земли.

Ключевые слова: учебник, университет, диссертация, оппонент, дискуссия, ландшафт.

Для цитирования: Федотов В.И. Три Николая и Федор Мильков // Вестник Воронежского государственного университета. Серия: География. Геоэкология, 2021, № 3, с. 111-122. DOI: https://doi. org/10.17308/geo.2021.3/3609
\end{abstract}

\section{ВВЕДЕНИЕ}

Николай Андреевич Гвоздецкий, Николай Иванович Михайлов, Николай Адольфович Солнцев и Федор Николаевич Мильков - представители НИИ-говского поколения физико-географов. Все четверо, хотя и в разное время, окончили аспирантуру Научно-Исследовательского Института Географии при Московского государственном университете им. М.В. Ломоносова.

Три Николая и один Федор - не коренные москвичи. Федор Мильков, как мы уже знаем, уроженец (1918) д. Доровая Вологодской губернии [16], Николай Михайлов (1915) из города Рыбинска, Николай Гвоздецкий рожден (1913) в Петербурге, а родные места Николая Адольфовича Солнцева (1902) находились вблизи станции Евье-Виленской губернии Российской империи.

Связав научно-педагогическую деятельность с географическим факультетом Московского университета, николаевское трио приобрело навсегда московскую прописку. В меру своего природного таланта, помноженного на целеустремленность, плюс принадлежность к самому титулованному

(С) Федотов В. И., 2021

$\triangle$ Федотов Владимир Иванович, e-mail: deanery@geogr.vsu.ru вузу страны МГУ позволило каждому занять свою нишу среди плеяды выдающихся географов отечества второй половины XX столетия.

Федор Мильков, напротив, связал свою научную судьбу с высшей школой на периферии. Сначала Чкаловский педагогический институт (1941-1950) на Южном Урале, а затем проработал до самой кончины (1950-1996) в Воронежском государственном университете в Черноземном крае.

За высочайший уровень научных достижений его почитали не только московские коллеги и коллеги других вузовских городов страны, но и зарубежное научное сообщество на трех из пяти обитаемых континентов мира - Северная и Южная Америка, Евразия.

\section{МАТЕРИАЛЫ И МЕТОДЫ}

Использованы при анализе взаимоотношений ученых опубликованные научные статьи и архивные материалы, хранившиеся у профессора Ф.Н. Милькова.

\section{РЕЗУЛЬТАТЫ И ОБСУЖДЕНИЕ}

Контакты и дружеские отношения с московскими коллегами у Федора Николаевича сложились по-разному.

(c) (i) Контент доступен под лицензией Creative Commons Attribution 4.0 License.

Вестник ВГУ, Серия: География. Геоэкология, 2021, № 3, 111-122 


\section{В.И. Федотов}

С Николаем Гвоздецким он был знаком еще с аспирантских времен - оба зачислены в аспирантуру НИИГа в 1938 году. А перед самой войной в 1941 году несколько месяцев работали на одной кафедре в МГУ - кафедра физической географии СССР. Так что времени для формирования товарищеских отношений у них было достаточно.

Совместных научных публикаций у Ф. Милькова и Н. Гвоздецкого не было, если не считать один крупный и долголетний проект по составлению учебника «Физическая география СССР». Написание учебника имело некоторую предысторию. Первоначально Министерство высшего и среднего специального образования СССР заключило договор о написании учебника с Н. А. Солнцевым. Но он его не выполнил, хотя сроки дважды переносились. И тогда Минвуз в 1956 году переадресовал условия договора на Ф.Н. Милькова.

Ф.Н. Мильков с присущей ему заинтересованностью и аккуратностью принимается за работу. Не считая себя специалистом по Средней Азии, Кавказу и Сибири, Федор Николаевич пригласил соавторами Н.А. Гвоздецкого и Н.И. Михайлова. Учебник по структуре состоял из двух частей. Первую - «Общий обзор. Европейская часть СССР. Кавказ» курировал Ф.Н. Мильков. Для написания раздела «Кавказ» он привлекает Н.А. Гвоздецкого как крупного хорошо знающего эту горную страну специалиста и давнишнего знакомого по НИИГу при МГУ. Н.А. Гвоздецкий к тому времени защитил две диссертации - в 1943 году кандидатскую «Орография Большого Кавказа», а в 1948 году блестяще защитил докторскую «Карстовые области Большого Кавказа и проблемы морфологии карста на основе их изучения».

Федор Николаевич вспоминал: «Сроки сдачи рукописи учебника в издательство «Мысль» катастрофически приближались. Мы согласовали с соавтором максимально скоро встретиться в Воронеже для корректуры текстов. Н. А. Гвоздецкий, как договаривались, появляется у меня на квартире и достает из своего ридикюля тысячестраничную рукопись «Кавказ», что составляло не менее $70 \%$ объема всего учебника. «Я ему в сердцах говорю, - ты что же не читал чеховского изречения - писать так, чтобы словам было тесно, а мыслям просторно». Он парировал - я не читатель, я писатель ${ }^{1}$. Выпили по стопке коньяка. Проводил Н.А. спать. А сам сел на кухне за обеденный стол корректировать его тексты. К утру все было гото- во. Передал «новую» рукопись «старому» автору. Он прочитал и сделал заключение - «Ты знаешь, стало лучше». В варианте Федора Николаевича раздел «Кавказ» Н.А. Гвоздецкого будет опубликован в негрифованном первом издании учебника «Физическая география СССР. Общий обзор. Европейская часть СССР. Кавказ» в 1958 году и в последующих четырех изданиях уже с грифом Минвуза.

В 1977 году Федор Николаевич опубликует статью «Оценка аква-территориальной схемы физико-географического районирования» [7], где будет реализован принцип единства природы континентальной суши и океана. При подготовке учебника «Физическая география СССР» к пятому изданию Ф.Н. предложит своим соавторам переделать его с учетом акватерриториальной схемы районирования. Н.А. Гвоздецкий был склонен к переработке учебника, а Н.И. Михайлов в личном письме к Ф.Н. сформулирует мотивированный отказ [6]. Пятое, последнее, издание учебника выйдет в свет в 1986 году с частичными изменениями и дополнениями, но фактически в старом варианте.

Н.А. Гвоздецкий охотно откликался на различные предложения Ф.Н. Милькова. Он неоднократный участник региональных и всесоюзных научных конференций, совещаний, симпозиумов, проходивших в Воронеже в разное время. Как председатель совета по присуждению ученых степеней на географическом факультете МГУ Н.А. лоббировал защиту докторской диссертации воронежца В. Б. Михно, а Федор Николаевич несколькими годами ранее организовывал защиту докторской диссертации А.Е. Фединой (МГУ) в Воронеже.

Н. А. Гвоздецкий соглашался без проблем выступать основным оппонентом диссертаций, подготовленных аспирантами Ф.Н. Милькова. В частности он оппонировал кандидатскую диссертацию «Ландшафтная структура известнякового севера Среднерусской лесостепи» В.И. Федотова. Примечательно, начало заседания совета по защите диссертации приняло некоторую тревожную детективную окраску. Но в конечном итоге все закончилось благополучно и для соискателя, и для руководителя, и для оппонента. А события с приездом Н.А. Гвоздецкого в Воронеже развивались следующим образом.

Николай Андреевич Гвоздецкий - доктор географических наук, профессор, заведующий кафедрой физической географии СССР Московского

\footnotetext{
${ }^{1}$ Биографы Н. А. Гвоздецкого подсчитают, что он написал более 800 научных статей и 54 персональных и коллективных монографии.
} 
госуниверситета, карстовед, знаток ландшафтов горных стран, историк науки, любитель живописи и музыки, великолепный рассказчик, автор многочисленных книг и научных текстов, очень занятой производственной и общественной деятельностью человек дал согласие на оппонирование моей кандидатской диссертации.

Максимально экономя свое время, он решил появиться в воронежском аэропорту не ранее чем за час до начала защиты, взяв билет на транзитный рейс Москва - Ростов-на-Дону с промежуточной посадкой в Воронеже. А вечером фирменным поездом вернуться в столицу, чтобы успеть к утреннему заседанию ученого совета географического факультета МГУ. Все настойчивые уговоры моего научного руководителя и председателя совета по защите диссертаций профессора Ф.Н. Милькова о заблаговременном приезде в Воронеж Н.А. Гвоздецким мотивировано откланялись. «Будь что будет, - заключил шеф. Но Вам, Владимир Иванович, обязательно следует встретить Николая Андреевича в аэропорту».

Стояли солнечные, заснеженные с легким морозцем предновогодние дни декабря 1969 года. К аэропорту с К.А. Дроздовым, вызвавшимся подстраховать, подъехали минут за двенадцать-пятнадцать до прибытия борта. В зале ожидания стесненная суета встречающих московский рейс. В справочном бюро получил самую неблагоприятную информацию - борт на подлете, но метеорологи считают, что из-за плотной дымки посадки может не быть. Самолет скорее всего проследует до Ростова-на-Дону.

Находиться в аэропорту, когда до начала работы совета оставалось не более сорока минут, становилось не целесообразным. Договорившись с сотрудницей справочного, что с Константином Александровичем через нее буду держать связь по городскому телефону (сотовых еще не было), вернулся в учебный корпус на Пушкинской. Перезвонил в аэропорт и получил сногсшибательную новость - «самолет прибыл - Гвоздецкого нет». «Кто передал Вам такое неправедное известие?»- поинтересовался шеф. «К.А. Дроздов, которого оставил ожидать рейс в аэропорту». «Другую кандидатуру не могли взять в помощники?», - без дальнейших комментариев высказался Федор Николаевич.

Заседание Совета началось вовремя, как того требовал регламент, но только с организационных вопросов. Председатель надумывал новые и новые проблемы, предлагал направления работы диссер- тационного совета на ближайшую перспективу. Было понятно, что он тянет время, рассчитывая на положительный исход запутанной ситуации. По сигналу шефа я несколько раз выходил на кафедру, чтобы справиться не появился ли здесь чудесным образом потерянный авторитетный оппонент. И возвращался в зал заседания без результата.

Bсе шло к тому, чтобы перенести защиту. Председатель снова подал согласованный сигнал. В отчаянии я вышел из учебного корпуса на улицу со стороны Кольцовского сквера. У дверей, подняв голову к вывеске «Воронежский государственный университет им. Ленинского комсомола», стоял в демисизонном пальто и шапке-ушанке профессор Гвоздецкий Николай Андреевич.

«Что же это Вы меня не встретили. Я уже более получаса брожу по центру. Был здесь однажды, но подзабыл. Теперь вот случайно набрел на прикрепленный к стене аншлаг».

«Конечно же встречали, но Вас зевнули», только и смог сказать ему в оправдание.

Защита прошла на «ура». В развернувшейся дискуссии с положительным вердиктом выступили незабвенные профессора университета - Борис Павлович Ахтырцев, Николай Алексеевич Плаксенко, Григорий Иванович Раскатов, Иван Николаевич Ежов.

Хорошо все то, что хорошо кончается.

Н.А. Гвоздецкий был инициатором участия Ф.Н. Милькова в конкурсе Русского географического общества на присуждение золотой медали П. П. Семенова. Идея Гвоздецкого Н.А. была поддержана Воронежским отделом РГО в 1966 году. В конкурсную комиссию направили пять опубликованных Ф.Н. Мильковым в разные годы изданий - 1) Физическая география СССР. Общий обзор. Европейская часть СССР. Кавказ. Изд. 2-е. М., Географгиз, 1962; 2) Средняя полоса Европейской части СССР. М., Географгиз, 1961; 3) Физико-географический район и его содержание. М., Географгиз, 1956; 4) Ландшафтная география и вопросы практики. М., Мысль, 1966; 5) Основные проблемы физической географии. М., Просвещение, 1969.

Пятилетняя эпопея с присуждением золотой медали П.П.Семенова закончилась в декабре 1970 года, когда на V съезде Географического общества СССР его президент С.В. Калесник объявил перечень лауреатов, где значилось имя Ф. Н. Милькова [11].

Н. А. Гвоздецкий, всякий раз приезжая в Воронеж по делам, непременно бывал гостем Милько- 
вых. И не только он, но и его родственники. Так, сын Гвоздецкого Игорь, гастролируя с сольным скрипичным концертом, зван был к обеду семьей Мильковых. Вечером того же дня Серафима Артемовна, Федор Николаевич и В. И. Федотов аплодировали его виртуозной игре в Воронежском музыкальном театре.

Федор Николаевич во время научных командировок в Москву неоднократно посещал семью Гвоздецких на Скатертном переулке, что за почтамтом на Новом Арбате.

Как мы наблюдали, после 1986 года отношения между Ф.Н. Мильковым и Н.А. Гвоздецким начали постепенно охладевать. Причина - провал защиты докторской диссертации Забелиным Игорем Михайловичем в совете при географическом факультете МГУ, где председателем был Н.А. Гвоздецкий. Федор Николаевич считал, что провал произошел по вине председателя, который пассивно реагировал на ход защиты, а затем и голосования. Публичное мнение Федора Николаевича на это событие иное - «винить следует не членов Ученого совета, имеющих право на свое мнение, а бюрократическое правило, запрещающее диссертанту выступать с отвергнутой работой перед членами другого Ученого совета» [10]. Стресс для Игоря Михайловича оказался трагичным. Через непродолжительное время он скончался от разрыва сердца, не дожив года до 60 лет.

С Николаем Ивановичем Михайловым Федора Милькова почти на протяжении полувека связывали неизменно дружеские отношения [6, с. 86]. И хотя по возрасту они были практически ровесники, научно-педагогическая карьера Михайлова существенно отставала от карьеры Ф.Н. Милькова. Н.И. Михайлов в 1945 году только поступил в аспирантуру при МГУ, а Федор Николаевич уже доцентом работал в Чкаловском педагогическом институте. В 1947 году Н.И. Михайлов защищает кандидатскую диссертацию - «Физико-географическая характеристика плато Путорана», а у Ф.Н. Милькова остается год до защиты докторской диссертации. В 1963 году по совокупности опубликованных работ Н.И. Михайлов защитил докторскую диссертацию на тему «Физико-географическое районирование и физическая география Сибири», а Ф.Н. Мильков к этому времени уже полтора десятилетия плодотворно трудился заведующим кафедрой физической географии в Воронежском госуниверситете.

Точно определить при каких обстоятельствах завязались дружеские отношения Николая Михай- лова и Федора Милькова теперь вряд ли возможно. Но предполагаем, что они скорее всего были связаны с публикационной активностью Николая Ивановича Михайлова, относящейся к итогам исследования гор Путорана. Николай Михайлов был первым географом, положившим начало изучения горных массивов и лавовых плато Путорана. Результаты наблюдений им были опубликованы в «Вопросах географии». Статья Н. Михайлова не осталась без внимания Федора Милькова. Спустя много десятилетий, Федор Николаевич вспоминал, что имя Н. И. Михайлова у него ассоциируется в первую очередь с 3-им выпуском «Вопросов географии» (1947). Сборник открывался статьей Н.И. Михайлова «Геоморфологические наблюдения в западной части гор Путорана [6].

А затем последовала их совместная работа над составлением учебника для университетов «Физическая география СССР», где Н.И. Михайлов и Н.А. Гвоздецкий были соавторами профессора Ф.Н. Милькова.

Николай Иванович Михайлов не был замечен на конференциях в Воронеже, посвященных изучению антропогенных ландшафтов. Более того нам доподлинно известно, что он отвергал антропогенное ландшафтоведение, как новое направление. На полях монографии В.И. Федотова «Техногенные ландшафты: теория, региональные структуры, практика» (Воронеж, 1985) он оставил нелестные карандашные пометки. Пройдет некоторое время и его коллеги по кафедре с большой заинтересованностью станут изучать проблемы антропогеогенеза.

Как нам сейчас представляется, личных контактов у Н.И. Михайлова и Ф.Н. Милькова было немного. «Территориальная разобщенность, как вспоминал Федор Николаевич, - стала поводом для активной переписки» [6, с. 86]. И все-таки трижды Н.И. Михайлов побывал в Воронеже с деловыми визитами. Ф.Н. Мильков вспоминал, что первый раз «в 1955 г. Н.И. Михайлов приезжал в Воронеж для обсуждения его «Избранных лекций» на кафедре физической географии. Как первый опыт лекционного курса книга вызвала у нас живой интерес и при общей положительной оценке подверглась жесткой критике. Последнее не нарушило его добрых отношений с воронежскими коллегами и в 60-х годах он вновь побывал в Воронеже в качестве оппонента на защите кандидатской диссертации В. И. Булатовым, а в конце 80-х годов - как член Научно-методического совета по географии» [6, с. 87]. 
Николай Иванович Михайлов - ученый одной проблемы. Ф.Н. Мильков по этому поводу напишет следующее: «При всех больших заслугах Н.И. Михайлова в региональной географии, как исследователя Сибири, основная масса вузовских географов знает его и чтит прежде всего как виднейшего специалиста в области физико-географического районирования, автора первых учебных пособий по новому для университетов спецкурсу «Физико-географическое районирование» [6, с. 86].

Высоко оценивая личные качества Николая Ивановича Михайлова - обязательность, прямота, деликатность, Федор Николаевич в статье к его 80-летию напишет очень лестные слова: «Я горжусь, что принадлежал к кругу его друзей» $[6$, c. 87$]$.

Николай Адольфович Солнцев был самым старшим среди выдающейся четверки. Разница в возрасте между ним и Федором Мильковым составляла 16 лет. Однако в карьерном продвижении к ученым степеням он в первые годы ненамного опережал своих друзей. Московский государственный университет по специальности «геоморфология» Солнцев закончит в 1935 году, когда ему уже было 33 года. Выпускной работой Николая Солнцева станет «Физико-географическая характеристика острова Колгуев». В 1938 году материалы дипломной работы будут опубликованы в «Ученых записках МГУ» в томе XIVна 64 страницах как «Остров Колгуев. Физико-географический очерк».

Интересную деталь в биографии Николая Адольфовича Солнцева отмечает его ученица и коллега по кафедре И.И. Мамай, позволившая предположить при каких обстоятельствах могло состояться первое знакомство Федора Милькова и Николая Солнцева. Оказывается, что будучи на 5 курсе (1934-1935) МГУ Н. Солнцев читал «Общее землеведение» в МОПИ [3], где первокурсник (1934-1935) Федор Мильков начинал свою студенческую жизнь.

Связь Н.А. Солнцева с северными территориями страны будет продолжаться вплоть до защиты им в 1940 году кандидатской диссертации на тему «Снежники как геоморфологический фактор». Кандидатская диссертация - результат его полевых исследований на острове Колгуев, Кольском полуострове, острове Диксон, островах Новой Земли.

На этом этапе собственно и заканчивается лидерство Николая Солнцева перед Федором Мильковым.
Только в возрасте 62 лет он в 1964 году защитит докторскую диссертацию по совокупности опубликованных научных работ. Николай Адольфович Солнцев в истории советского ландшафтоведения остается пионером в разработке проблемы морфологии ландшафта.

Во взаимоотношениях Ф.Н. Милькова и Н.А. Солнцева хорошо просматриваются три неравных по продолжительности периода: дружба - конфликт - примирение.

Дружба. Начало дружбы Николая Солнцева и Федора Милькова, по-видимому, относится к середине, а скорее всего ближе к концу 30 -х годов. В личной библиотеке Федора Николаевича, которую он частично передал на хранение еще при жизни в фонды Научной зональной библиотеке ВГУ, хранится оттиск публикации «остров Колгуев» с дарственной записью: «Дорогому товарищу Федору Николаевичу Милькову на память от автора. Ник. Солнцев. 9.ІІІ.1940. Москва».

Нам доподлинно известно, что в эти годы Федор Николаевич был вхожим в семью Н. Солнцева и И. Васильевой преподавателя Московского областного педагогического института. С самых детских лет хорошо знал сына Николая Адольфовича Владимира Солнцева, которого всегда уважал и при случае поощрял своим вниманием. Спустя много лет, в период конфликтных отношений с его отцом, Федор Николаевич откликнулся поощрительной рецензией на монографию В.Н. Солнцева «Системная организация ландшафтов (проблемы методологии и теории)» (М.: Мысль, 1981) [1].

В одной из приватных бесед Федор Николаевич поведает, что они на квартире у Н. Солнцева и И. Васильевой составляли официальный отзыв на его кандидатскую диссертацию. В личном архиве Ф.Н. Милькова отзыв Н.А. Солнцева хранился в течение 55 лет. И только в последней прижизненной статье [9] он упомянет о его существовании в связи с изменением взглядов на географический ландшафт «раннего» Н.А. Солнцева и представления его о ландшафте в опубликованных позже работах $[13,14]$.

В отзыве Н. А. Солнцева, официального оппонента, содержалось много лестных суждений о молодом исследователе, его таланте и оригинальных подходах к организации научной работы. По этой причине мы решили поставить в статью официальный отзыв Н.А. Солнцева на диссертацию Ф.Н. Милькова без купюр.

В контексте последовавших затем между ними конфликтных отношений этот отзыв можно было 
бы назвать как «Официальный монолог молодого Н.А. Солнцева своему юному другу соискателю научной степени Федору Милькову».

Отзыв

О диссертации Ф.Н. Милькова «Опыт характеристики ландшафтных районов северной лесостепи» на соискание ученой степени кандидата географических наук (221 стр. без списка литературы плюс приложение на 15-ти таблицах из карт и фото).

Работа Ф. Н. Милькова «Опыт характеристики ландшафтных районов северной лесостепи» (бассейна реки Пары и Паро-Пронского междуречья), как показывает само название, является попыткой дать ландшафтную характеристику одного из районов лесостепной зоны Русской равнины. Проблема географического ландшафта все еще находится в начальной стадии разработки, хотя она и привлекает к себе за последнее время внимание целого ряда географов. Однако она может быть удовлетворительно разрешена не в тиши кабинетов, а лишь в самой природе. Только после того как будут изучены в ландшафтном отношении отдельные районы, когда накопится опыт такого изучения, выработаются свои приемы исследования и их методика, - можно будет считать, что эта важная географическая проблема вступила в фазу серьезного научного разрешения. В этом отношении работа Ф.Н. Милькова, как попытка изучения и описания конкретных ландшафтных районов, представляет большой интерес.

Автор вполне правильно поступил, избрав для изучения участок лесостепи, ибо в этой переходной зоне, являющейся ареной борьбы между лесом и степью, легче найти ключ к правильному пониманию географического ландшафта, легче уяснить себе его внутреннюю сущность, вскрыть тот механизм, который формирует ландшафт.

Диссертация написана на основании как личных полевых исследований, так и по имеющимся литературным данным. Собственные наблюдения Ф.Н. Милькова показывают, что он может быть причислен к числу наблюдательных и тщательных исследователей, имеющих хорошую подготовку в геологии, геоморфологии, ботанике, почвоведении и других дисциплинах, знакомство с которыми совершенно необходимо географу-ландшафтоведу. Тот факт, что Ф.Н. Мильковым обнаружены неизвестные для Рязанской области виды растений (Najas marina и др.) ${ }^{1}$ показывает насколько внимательно и тщательно ведутся им разнообразные полевые работы.

С другой стороны, автор проделал огромную работу по отысканию и использованию множества мелких рассыпанных по разным изданиям печатных работ, так или иначе касающихся его диссертации. Он ознакомился со всей, оказавшейся доступной неопубликованной рукописной литературой, находящейся в фондах различных учреждений, музеях и у частных лиц. Можно смело сказать, что в списке литературы, приложенном к его труду, приведены все работы, посвященные описанию природы района.

Кроме того, автор обнаруживает хорошее знакомство с широкой географической и специальной литературой, касающейся вопросов, с которыми ему приходится сталкиваться.

В своей работе Ф.Н. Мильков умело использует личные полевые наблюдения и литературные данные.

Нужно также отметить, что работа была написана хорошим литературным языком и культурно построена. Всюду имеются ссылки на литературу; приведен прекрасный «Обзор основной печатной литературы по природе бассейна реки Пары», где читатель в кратких аннотациях может познакомиться с содержанием каждой статьи или книги, узнать какие важнейшие вопросы она ставит; приложен список цитируемой литературы, насчитывающий 128 наименований и использованных карт.

Вся работа Ф.Н. Милькова может быть разбита на 3 главные части. В первой части («Введение») автор останавливается на понятии «ландшафт» и разбирает существующие определения этого понятия у разных авторов; в заключении дает свое определение ландшафта. Вторая часть работы посвящена описанию элементов ландшафта - климата, геологического строения, рельефа, подземных вод, почв, растительности и животного мира. Третья часть посвящена описанию отдельных ландшафтных районов.

Уже в первой части («Введение»), автор обнаруживает основательное знакомство с литературой по вопросу о географическом ландшафте на русском и на немецком языках. Надо отметить, что русская литература им использована почти исчерпывающе. Автор критически разбирает главнейшие определения ландшафта русских географов и указывает, что его понимание ближе всего подходит к пониманию ландшафта С.С. Неуструевым. Он пишет,

\footnotetext{
Najas marina - наяда морская в определителе П.Ф. Маевского «Флора средней полосы Европейской части СССР» (Ленинград: издательство «Колос», 1964) в Рязанской области не указывается.
} 
что «природный ландшафт в нашем понимании есть совокупность взаимообусловленных элементов природы, предстающих перед нами в образе тех или иных исторически сложившихся, находящихся в постоянном развитии, пространственных группировок». В этом определении совершенно правильно подчеркнута идея непрерывного развития ландшафта, а значит и его историчность и динамичность, как противопоставление идеи «гармоничности» в ландшафте. Однако автору, следовало бы в этом определении особо подчеркнуть роль человека, как мощного фактора обязательно участвующего в формировании ландшафтов, но практически в своих описаниях мало уделяют внимания этому могучему деятелю и не вскрывают с должной полнотой его преобразующую роль.

Совершенно правильно Ф.Н. Мильков считает необходимым в каждом ландшафте искать «ведущий» фактор, опираясь на который можно правильно вскрыть и оценить роль всех остальных. Это теоретическое положение в дальнейшем очень плодотворно применяется им при описании ландшафтных районов.

Удачной может считаться и предлагаемая автором таксономическая схема: тип ландшафта (ландшафты низменных равнин, ландшафты гор), ландшафтная зона, ландшафтная провинция, ландшафтная область, ландшафтный район.

В лесостепной зоне Русской равнины автор выделяет три ландшафтных провинции: 1) Западную (Днепровскую), 2) Центральную (Среднерусскую) и 3) Восточную (Волжскую). Выделение этих провинций производится по ведущему признаку - степени континентальности. Выделение ландшафтных областей автор производит на основе однородности (в общих чертах) геологического строения и рельефа. Наконец ландшафтные районы выделяются на основании геоморфологических признаков и совпадают с геоморфологическими районами.

Таким образом район, которому посвящена разбираемая работа, входит в ландшафтную область Окско-Донской низменности, Среднерусской ландшафтной провинции лесостепной зоны.

Во второй части работы, посвященной элементам природы, сведены в стройную картину материалы личных наблюдений и литературных данных. Эта часть построена вполне логично и дает в качестве предпосылки богатый материал для последующего описания ландшафтных районов. На исследованной территории автор выделяет 5 ландшафтных районов:
1) Окско-Донская водораздельная равнина с пятнами западных лесов на черноземе; 2) Сапожковская моренная равнина с островами водораздельных дубрав на деградированном черноземе и серых лесостепных почвах; 3) Долины рек Пары и ее главных притоков с аллювиальными почвами, пойменными лугами и черноольшаниками, 4) Песчаная равнина правобережья реки Пары со смешанными лесами на серых лесостепных и подзолистых почвах, 5) Долина Оки с аллювиальными почвами и дубравами среди пойменных лугов.

В описании каждого из перечисленных районов автор рассматривает ландшафт, согласно своему определению, данному во «Введении», в динамике и развитии. Он удачно вскрывает главнейшие факторы, формирующие каждый ландшафт, показывает внутренние связи и взаимообусловленность. Однако нужно отметить, что роли человека - одного из самых мощных преобразователей ландшафта, создавших его современную физиономию, уделено недостаточно внимания. Не сделал автор и попытки показать, что нужно сделать в его ландшафтных районах, чтобы они хотя отчасти восстановили утраченные нерациональным хозяйничаем человека черты; не указано (за некоторыми исключениями) какие мероприятия могут привести к еще большему обеднению географического ландшафта.

К числу недостатков работы надо отнести слишком большую категоричность автора при высказывании по спорным или недоказуемым прямыми наблюдениями положений. Так, например, автор без всяких оговорок категорически утверждает, что в его районе большую роль играют суффозионные процессы. При этом он считает, что там имеет место не только химическая, но и механическая суффозия. По его мнению, «не только воронки, но и пещеры длиной до 3-х метров (стр. 76) образуются в результате суффозионных процессов». Однако, никаких других доказательств, кроме описания наблюдающихся форм рельефа он не приводит. Между тем следовало бы привести и подтверждения своего мнения какие-нибудь другие доказательства. Это тем более важно, что целый ряд ученых, как на это справедливо указывает автор (стр. 98), вообще ставят под сомнение вопрос о возможности суффозионных (механической суффозии) процессов и именно в том виде, как они мыслятся автором.

В разделе, посвященном истории развития рельефа автор утверждает, что доледниковый рельеф характеризовался небольшими колебаниями отно- 


\section{В.И. Федотов}

сительных высот и незначительной расчлененностью, что гидрографическая сеть резко отличалась от современной и т.д. (стр. 99). Однако выше мы находим сетования автора на крайне скудную обнаженность района и на чрезвычайно малое количество буровых данных. Спрашивается-какие же фактические данные позволяют ему так уверенно рисовать картину доледникового рельефа?

Касаясь вопроса о Лихвинском оледенении, он говорит, что «его южная окраина проходила вблизи от северо-западной границы нашего района» (стр. 99). На основании каких материалов автор так точно устанавливает эту границу - неизвестно.

Еще большая предвзятость взглядов существует у автора по вопросам о «степных блюдцах». Он категорически утверждает, что «гипотеза образования западин путем уменьшения объема и пористости лессовидных пород при смачивании водой не выдерживает критики» (стр. 98), хотя причина образования степных блюдец именно таким способом доказана для целого ряда мест и наблюдениями, и экспериментальными данными. Работы К. М. Лисицына и, особенно, П. В. Мартынова на Терско-Кумской и Малокабардинской оросительных системах показали, что просадки, создающие типичные степные блюдца, происходят как раз при смачивании водой лессовидных пород, и что это происходит благодаря растворению содового цемента и уменьшения объема породы.

Вообще по вопросу о происхождении степных блюдец у автора существует значительная путаница. Хотя он и говорит, «что если каждая западина и есть прежде всего простое понижение рельефа, то не каждое простое понижение рельефа может быть названо степным блюдцем или западиной» (стр. 97). Однако далее он рассматривает все западины на равнинных поверхностях вместе, не отмечая степных западин, метко названных В. Докучаевым «степными блюдцами», от западин на моренных поверхностях района бассейна Пары и даже остатков стариц на верхних террасах. Так, на странице 181 он говорит, что «старицы, озерки и другие неровности бывшей поймы постепенно выравнивались; на месте их остались слабо заметные понижения, превратившиеся впоследствии в типично степные блюдца или западины». Автор считает, что процессы механической и химической суффозии формируют многие западины. Таким способом по его мнению образуются западины и на морене, и на песках (стр. 98). Доказать образование западин путем суффозии на водонепроницаемой морене конечно, бесплодная задача.
К числу недостатков работы следует отметить неудачное название геоморфологических районов на карте. Так северный район назван «Мягко-волнистая моренная равнина Паро-Пронского междуречья с плащами делювиальных суглинков по пологим склонам». Исходя из этой картины можно заключить, что основные типы рельефа междуречий имеют моренный рельеф. На самом деле, как это следует и из описания, это типичный эрозионный рельеф, достигший зрелой стадии (асимметричные водораздельные пространства), хотя он и сформировался на моренной поверхности. В другом месте, на стр. 150, автор говорит даже о «первичном рельефе Паро-Пронского междуречья». Что здесь сильно переработанный рельеф, а не первичный - ясно из предыдущего.

Автору не удалось в своей работе избежать общей ошибки большинства географов, занимающихся исследованиями и описанием современных ландшафтов, а именно склонность обращать большое внимание только на те объекты, которые меньше подверглись преобразовательному влиянию человека, т.е. стремление обращать главное внимание на «естественный ландшафт».

А между тем в районе работ автора, с густым населением давно уже освоившим территорию, ландшафт сильнейшим образом изменен человеком. Следовательно, надо было показать и то отрицательное, что внесено в ландшафт человеческой деятельностью, объяснить как и почему это произошло. Ф.Н. Мильков во многих местах говорит об этой роли человека только общими словами или даже совсем отмахивается от характеристики участков измененных человеком. Так, например, на стр. 132, касаясь соснового леса на левобережье реки Похвы у села Кутловы Борки, он прямо говорит, что эти лесные участки «так изменены вмешательством человека, что не представляют никакого интереса».

В главе о животном мире автор пишет, что «еще более значительному истреблению со стороны человека подверглось животное население района; и в настоящее время роль животных, как элемента ландшафта настолько мала, что мы подчеркнем при его описании одну основную особенность, а именно - смешанный характер форм, с одной стороны типичных лесных, - с другой стороны типично степных». На самом деле это не так. Изменение ландшафта человеком привело не столько к истреблению животного мира, сколько к истреблению первичных и необходимых местообитаний. Дикие обитатели, населявшие эти ме- 
ста прежде, были таким способом вытеснены из района, а на их месте поселились другие. И вот новые пришельцы, спутники нового ландшафта, сильно преобразованного человеком, почему-то уже не привлекают к себе внимания автора. Здесь мы опять-таки видим увлечения «естественным ландшафтом», желание считать элементом ландшафта только животный мир, не преобразованной человеческим вмешательством, лесостепи.

Мелкие и второстепенные замечания указаны мною дополнительно в соответствующих местах рукописи.

Однако указанные частные недостатки ни в коей мере не умаляют общих высоких достоинств работы Ф.Н. Милькова. Наоборот в его работе мы видим новый шаг вперед в разрешении проблемы географического ландшафта и в методике его описания. Избежать некоторых недостатков в работе такого порядка трудно, ибо мы до сих пор еще не имеем образцов, по которым следует ровняться. Поэтому нужно считать, что автор весьма успешно справился с поставленной перед собою задачей и за его работу вполне может быть присвоена ученая степень кандидата географических наук.

11/VI-1941 года.

кандидат географ. наук,

/ Н. А. Солнцев / доцент

Из дискуссии, содержащейся в отзыве, видна еще одна проблема, а не только понимание географического ландшафта, проблема изменения ландшафта человеком. Анализ этой проблематики А.Н. Солнцевым в отзыве показывает, что по пониманию совершающихся в природе рукотворных преобразований, он был ближе к обоснованию антропогенного ландшафтоведения в 40-х годах, чем Ф.Н. Мильков в конце 60 -х, когда оно было поставлено им как важнейшее научно-прикладное направление в науках о Земле [4].

Конфликт. Причину конфликта между Н.А. Солнцевым и Ф.Н. Мильковым ни при их жизни, ни тем более теперь нет возможности установить. Однако предположить есть основания.

Существуют несколько сближенных дат. 1. Спустя 7 лет после защиты кандидатской диссертации, в 1948 году Ф.Н. Мильков защищает докторскую. Научный консультант у тридцатилетнего соискателя сам академик А. А. Григорьев. Думаем, что многих это возбуждало. 2. В 1949 году в печати появляется резко критическая рецензия Н. А. Солнцева на статью Ф.Н. Милькова, опубликованную в Известиях Чкаловского отдела Географического общества СССР [12]. В рецен- зии содержатся непростые выражения. Например, по отношению к определению Ф.Н. Мильковым географического ландшафта Николай Адольфович делает такое обобщение - «это определение нам кажется односторонним, не учитывающим истории развития ландшафтов и поэтому по существу неправильным» (с. 200). Обвиняет рецензент $Ф . Н$. Милькова в том, что он делает «неверный вывод» (с. 202) о понимании Л.С. Бергом содержания термина фация. Находим в рецензии и такое заключение - «также он (Ф.Н. Мильков) не прав, считая, что ландшафтовед не должен заниматься изучением природных комплексов, составляющих «ландшафтный район» (с. 202). В конце рецензии Н.А. Солнцев делает резюме - «Таким образом, статья Ф.Н. Милькова, затрагивая интересный и важный для нашей науки вопрос, содержит целый ряд ошибочных заключений и установок» (с. 203). 3. В том же 1949 году Н. А. Солнцев публикует две программные статьи о своем взгляде на географический ландшафт и ведущий фактор (литогенную основу) его формирования. В выборе фактора, как нам представляется, сказалась узкая профессиональная специальность Н. А. Солнцева геоморфология.

Принципиально конструкция ландшафтной концепции Н.А. Солнцева и его научная продуктивность со временем затормозилась. А.Г. Исаченко обратит внимание как раз на эту сторону научного творчества Н.А. Солнцева [2, с. 377-378]. А его «ученик», бывший соискатель, в это время буквально семимильными шагами двигался вперед, публикуя одну за другой статьи и монографии ландшафтоведческого направления - О морфологических и генетических типах ландшафтов-аналогов (Труды 2-го Всесоюзного Географического съезда (1948); О некоторых географических закономерностях, вытекающих из анализа ландшафтных зон Русской равнины (сб. Проблемы физической географии, 1949); Лесостепь Русской равнины (М., 1950); Лесостепной ландшафт и его зональное подразделение (Изв. АН СССР. Сер. географ., 1951. № 5); К анализу ландшафтных (физико-географических) рубежей на Русской равнине (Изв. Всесоюзн. Географ. о-ва, 1952, вып. 1); Таксономия ландшафтных единиц и некоторые вопросы ландшафтного картирования (Тр. Воронеж. гос. ун-та, 1953); Типы местности и ландшафтные районы Центральных Черноземных областей (к вопросу о выделении региональных и типологических единиц в ландшафтной географии) (Изв. Всесоюз. Геогр. о-ва, 1954, вып. 4); 
Генетический принцип, его роль и значение в физико-географическом районировании (Тр. Воронежского университета, $1955^{1}$, вып. 4); Физико-географический район и его содержание (М., 1956); Ландшафтные районы Центральных Черноземных областей (Тp. Воронежского университета, 1957, Т. 37); О двухъярусной структуре равнинных ландшафтов (Науч. докл. высш. шк. Геолого-геогр. науки, 1958, № 1); К вопросу о существовании ландшафтной сферы Земли и месте ландшафтоведения в системе физико-географических наук (Науч. докл. высш. шк. Геолого-геогр. науки, 1959, № 1). За десятилетие (1949-1959) Ф.Н. Мильков опубликует 102 статьи, монографии, книги.

В 1956 году Ф.Н. Мильков в «Вопросах географии» (№39) публикует дискуссионную статью, где корректно обосновывает нецелесообразность различать фацию как морфологическую единицу ландшафта. «Итак, - пишет Ф.Н. Мильков, - по всем данным фация Н. А. Солнцева и биогеоценоз В.Н. Сукачева - идентичные понятия [8, с.86].

Заочное соперничество с Н.А. Солнцевым за лидерство в ландшафтоведении продолжалось. Но при этом сохранялись относительно ровные личные отношения. Так, например, они в 1959 году отдыхали на море в Крыму вместе с географической элитой страны.

Конфликтная ситуация достигла апогея в 1960 году, когда была опубликована коллективная монография «Физико-географическое районирование СССР. Обзор опубликованных материалов» под редакцией двух Николаев - Н. А. Гвоздецкого и Н.И. Михайлова.

Монография открывалась главой «История физико-географического районирования Европейской части СССР», автором которой был Н.А. Солнцев. Он, не стесняясь в выражениях, «разносит» сетку физико-географического районирования Русской равнины, предложенную Ф.Н. Мильковым. Приведем лишь некоторые самые крепкие. Например, «привело Ф.Н. Милькова к шаткости его теоретических построений» (с.73), «принцип чередования зональных и азональных факторов надуман» (c. 47), «основные теоретические положения, на которых зиждется система районирования Ф.Н. Милькова, как мы видим, что они противоречивы, плохо обоснованы» (с. 48) и другие. Не спасли ситуацию и замечания редакторов о том, «что в статье Н.А. Солнцева, по мнению редакции, два последних раздела недостаточно объективно освещают вопросы, подлежащие обсуждению, и во многих отношениях являются весьма спорными» (с. 5).

Статья Н.А. Солнцева, по-видимому, стала главной причиной разрыва отношений на долгие десятилетия. Нам представляется, что в одной из последних статей, посвященных А.А. Григорьеву, Ф.Н. Мильков оценит критику 1960 года Н.А. Солнцева следующим образом: «важнейшая черта его [А.А. Григорьева] характера - предельная объективность в изложении дискуссионных вопросов, полное отсутствие в публикациях пустых, но красивых, фраз, рассчитанных на сиюминутный успех; убеждение читателя в своей правоте логикой и фактами, а не громкими неуважительными выражениями в адрес оппонента» [5, с. 64].

Примирение. Нам известно со слов Федора Николаевича, что незадолго до кончины Н.А. Солнцев пришлет ему покаянное письмо. Комментариев более подробных со стороны Ф.Н. Милькова не было.

\section{ЗАКЛЮЧЕНИЕ}

Девяностые годы XX столетия - время ухода из жизни ярких, самобытных, бескомпромиссных ученых, оставивших значительный багаж знаний о природе нашей Земли. Три Николая и один Федор свой жизненный путь заканчивали в разные годы, но в один климатический сезон - осень. Николай Адольфович Солнцев скончался 6 ноября 1991 года (Москва), Николай Иванович Михайлов - 30 октября 1992 (Москва), Николай Андреевич Гвоздецкий - 10 октября 1994 (Москва), Федор Николаевич Мильков - 15 октября 1996 года (Воронеж).

\section{СПИСОК ЛИТЕРАТУРЫ}

1. Боков В.А., Геренчук К.И., Мильков Ф.Н. Несколько точек зрения на оригинальный труд по теории ландшафтных систем // Вестник Московского университета. Серия 5. География, 1982, №3, с. 96-98.

2. Исаченко А.Г. Избранные труды (к 90-летию со дня рождения). Спб.: Издательствово «ВВМ», 2012. $486 \mathrm{c}$.

3. Мамай И.И. Николай Адольфович Солнцев (к 100-летию со дня рождения) // Известия Русского географического общества, 2002, т. 134, вып. 3, с. 1-6.

4. Мильков Ф.Н. Антропогенное ландшафтоведение и вопросы краеведения в высшей школе // Материалы 2-ой межвузовской научно-методической конференции по вузовскому и школьному краеведению «Вопросы вузовского и школьного краеведения», 1969, с. 50-53.

5. Мильков Ф.Н. В бессрочной докторантуре у Андрея Александровича Григорьева // Известия РАН. Серия Географическая, 1997, №5, с. 61-66.

${ }^{1}$ В 1955 году в Ленинграде состоится 1-ое совещание по ландшафтоведению, где будет бенефис троих - Ф. Н. Милькова, А. Г. Исаченко, Д. Л. Арманда. Н. А. Солнцев на совещании не присутствовал [15]. 
6. Мильков Ф.Н. Николай Иванович Михайлов и проблемные вопросы физико-географического районирования // Вестник Московского университета. Серия 5. География, 1995, №4, с. 86-89.

7. Мильков Ф.Н. О единой аква-территориальной схеме физико-географического районирования // Проблемы природного районирования. Уфа, 1977, с. 11-16.

8. Мильков Ф.Н. О некоторых дискуссионных вопросах ландшафтной географии // Вопросы географии, 1956 , № 39, с. 80-89.

9. Мильков Ф.Н. Похвальное слово о научно-исследовательском институте географии МГУ (к 75-летию со дня рождения) // Вестник Московского университета. Серия 5. География, 1996, №4, с. 3-8.

10. Мильков Ф.Н. Страницы творческой биографии Игоря Михайловича Забелина (1927-1986) // Известия РАН. Серия Географическая, 1996, № 4, с. 126-134.

11. Нестеров Ю.А., Нестеров А. И. Под эгидой Русского географического общества (к 95-летию со дня рождения Ф.Н. Милькова) // Вестник ВГУ. Серия: География. Геоэкология, 2013, № 1, с. 220-226.

12. Солнцев Н.А. Мильков Ф.Н. О понятии физико-географического ландшафта и системе ландшафт- ных единиц // Известия Чкаловского отдела Географического общества СССР, 1949, сб. 16, с. 200-203.

13. Солнцев Н.А. О морфологии природного географического ландшафта // Вопросы географии. Москва, 1949, сб. 16, с. 61-86.

14. Солнцев Н.А. Природный географический ландшафт и некоторые общие его закономерности // Труды Второго Всесоюзного Географического съезда. Москва, Географгиз, 1949, т. 1, с. 259-269.

15. Федотов В. И., Федотов С. В. К 60-летию первого Ленинградского совещания по вопросам ландшафтоведения // Вестник ВГУ. Серия: География. Геоэкология, 2015, № 3, с. 3-6.

16. Федотов В.И., Федотов С.В. Профессор Ф.Н. Мильков. Место рождения, родословная // Вестник Воронежского государственного университета. Серия: География. Геоэкология, 2019, №2, с. 108-110. DOI: https://doi.org/10.17308/geo.2019.2/2316

Конфликт интересов: Автор декларирует отсутствие явных и потенциальных конфликтов интересов, связанных с публикацией настоящей статьи.

Поступила в редакиию 23.12.2020 Принята к публикаичи 03.09.2021

UDC 911.5

DOI: https://doi.org/10.17308/geo.2021.3/3609

ISSN 1609-0683

\title{
The Three Nikolai and Fyodor Milkov
}

\author{
V.I. Fedotov $\bowtie$ \\ Voronezh state University, Russian Federation \\ (1, Universitetskaya pl., Voronezh, 394018)
}

\begin{abstract}
The purpose of the article is to introduce the geographical community with new biographical materials about Professor F. N. Milkov.

Materials and methods. We used published scientific articles and archival materials of professor F. N. Milkov in the analysis of relations between scientists.

Results and discussion. The article focuses on professional and personal relationships between Prof. F. N. Milkov and three well-known in science professors of the geographical faculty of Moscow University N.A. Gvozdetsky, N. I. Mikhailov and N.A. Solntsev. The focus is on problems of scientific cooperation, friendship and conflicts.

Conclusion. Nineties of the twentieth century - the time of death of bright, original, uncompromising scientists, who left a significant baggage of knowledge about the nature of our Earth.
\end{abstract}

Key words: textbook, university, thesis, opponent, discussion, landscape.

For citation: Fedotov V.I. Three Nikolai and Fyodor Milkov. Vestnik Voronezskogo gosudarstvennogo universiteta. Seria: Geografia. Geoekologia, 2021, no.3, p. 111-122. DOI: https://doi.org/10.17308/geo.2021.3/3609

(C) Fedotov V.I., 2021

Vladimir I. Fedotov, e-mail: deanery@geogr.vsu.ru

(c) (i) The content is available under Creative Commons Attribution 4.0 License. 


\section{REFERENCES}

1. Bokov V.A., Gerenchuk K. I., Mil'kov F. N. Neskol'ko tochek zreniya na original'nyy trud po teorii landshaftnykh sistem [Several points of view on the original work on the theory of landscape systems]. Vestnik Moskovskogo universiteta. Seria 5. Geografia, 1982, no. 3, pp. 96-98. (In Russ.)

2. Isachenko A. G. Izbrannye trudy ( $k$ 90-letiyu so dnya rozhdeniya) [Selected Works (on the occasion of the 90th birthday)]. St. Petersburg: Izdatel'stvo «VVM», 2012. 486 p. (In Russ.)

3. Mamay I. I. Nikolay Adol'fovich Solntsev (k 100-letiyu so dnya rozhdeniya) [Nikolay Adolfovich Solntsev (to the 100th anniversary of his birth)]. Izvestiya Russkogo geograficheskogo obshchestva, 2002, vol. 134, v. 3, pp. 1-6. (In Russ.)

4. Mil'kov F. N. Antropogennoe landshaftovedenie i voprosy kraevedeniya $\mathrm{v}$ vysshey shkole [Anthropogenic landscape science and local history issues in higher education]. Materialy 2-oy mezhvuzovskoy nauchno-metodicheskoy konferentsii po vuzovskomu i shkol'nomu kraevedeniyu "Voprosy vuzovskogo i shkol'nogo kraevedeniya», 1969, pp. 50-53. (In Russ.)

5. Mil'kov F.N. V bessrochnoy doktoranture u Andreya Aleksandrovicha Grigor'yeva [In an indefinite doctoral program with Andrey Alexandrovich Grigoriev]. Izvestiya RAN. Seria Geograficheskaya, 1997, no. 5, pp. 61-66. (In Russ.)

6. Mil'kov F. N. Nikolay Ivanovich Mikhaylov i problemnye voprosy fiziko-geograficheskogo rayonirovaniya [Nikolay Ivanovich Mikhailov and problematic issues of physical and geographical zoning]. Vestnik Moskovskogo universiteta. Seria 5. Geografia, 1995, no. 4, pp. 86-89. (In Russ.)

7. Mil'kov F. N. O edinoy akva-territorial'noy skheme fiziko-geograficheskogo rayonirovaniya [About a unified aqua-territorial scheme of physical and geographical zoning]. Problemy prirodnogo rayonirovaniya. Ufa, 1977, pp. 11-16. (In Russ.)

8. Mil'kov F. N. O nekotorykh diskussionnykh voprosakh landshaftnoy geografii [On some controversial issues of landscape geography]. Voprosy geografii, 1956, no. 39, pp. 80-89. (In Russ.)

9. Mil'kov F. N. Pokhval'noe slovo o nauchno-issledovatel'skom institute geografii MGU (k 75-letiyu so dnya rozhdeniya) [A word of praise for the Research Institute of

\section{Федотов Владимир Иванович}

доктор географических наук, профессор кафедры рекреационной географии, страноведения и туризма факультета географии, геоэкологии и туризма Воронежского государственного университета, г. Воронеж, Российская Федерация, ORCID: 0000-0002-2753-4702, e-mail: deanery@geogr.vsu.ru
Geography of Moscow State University (on the occasion of the 75th birthday)]. Vestnik Moskovskogo universiteta. Seria 5. Geografia, 1996, no. 4, pp. 3-8. (In Russ.)

10. Mil'kov F.N. Stranitsy tvorcheskoy biografii Igorya Mikhaylovicha Zabelina (1927-1986) [Pages of the creative biography of Igor Mikhailovich Zabelin (1927-1986)]. Izvestiya RAN. Seria Geograficheskaya, 1996, no. 4, pp. 126-134. (In Russ.)

11. Nesterov Yu.A., Nesterov A.I. Pod egidoy Russkogo geograficheskogo obshchestva (k 95-letiyu so dnya rozhdeniya F.N. Mil'kova) [Under the auspices of the Russian Geographical Society (to the 95th anniversary of the birth of F. N. Milkov)]. Vestnik VGU. Seria: Geografia. Geoekologia, 2013, no. 1, pp. 220-226. (In Russ.)

12. Solntsev N.A. Mil'kov F. N. O ponyatii fiziko-geograficheskogo landshafta i sisteme landshaftnykh edinits [Milkov F.N. On the concept of physical-geographical landscape and the system of landscape units]. Izvestiya Chkalovskogo otdela Geograficheskogo obshchestva SSSR, 1949, col. 16, pp. 200-203. (In Russ.)

13. Solntsev N.A. O morfologii prirodnogo geograficheskogo landshafta [On the morphology of the natural geographic landscape]. Voprosy geografii. Moscow, 1949, col. 16, pp. 61-86. (In Russ.)

14. Solntsev N.A. Prirodnyy geograficheskiy landshaft i nekotorye obshchie ego zakonomernosti [Natural geographic landscape and some of its general patterns]. Trudy Vtorogo Vsesoyuznogo Geograficheskogo s"ezda. Moscow, Geografgiz, 1949, vol. 1, pp. 259-269. (In Russ.)

15. Fedotov V.I., Fedotov S. V. K 60-letiyu pervogo Leningradskogo soveshchaniya po voprosam landshaftovedeniya [On the occasion of the 60th anniversary of the first Leningrad conference on landscape studies]. Vestnik VGU. Seria: Geografia. Geoekologia, 2015, no. 3, pp. 3-6. (In Russ.)

16. Fedotov V. I., Fedotov S. V. Professor F. N. Mil'kov. Mesto rozhdeniya, rodoslovnaya [Professor F. N. Milkov. Place of birth, pedigree]. Vestnik Voronezhskogo gosudarstvennogo universiteta. Seria: Geografia. Geoekologia, 2019, no. 2, pp. 108-110. DOI: https://doi.org/10.17308/ geo.2019.2/2316 (In Russ.)

Conflict of interests: The author declares no information of obvious and potential conflicts of interest related to the publication of this article.

Received: 23.12.2020 Accepted: 03.09.2021

Vladimir I. Fedotov

Dr. (Geogr.) Sci., Professor of the Department of Recreational Geography, Country Studies and Tourism, Faculty of Geography, Geoecology and Tourism, Voronezh State University, Voronezh, Russian Federation, ORCID: 00000002-2753-4702, e-mail: deanery@geogr.vsu.ru 